\title{
Holstein-Friesian calves selected for divergence in residual feed intake during growth exhibited significant but reduced residual feed intake divergence in their first lactation
}

\author{
K. A. Macdonald, ${ }^{\star 1}$ J. E. Pryce,†‡ R. J. Spelman,§ S. R. Davis,§ W. J. Wales,\# G. C. Waghorn, ${ }^{\star}$ Y. J. Williams,॥ \\ L. C. Marett,\# and B. J. Hayes†‡ \\ *DairyNZ, Hamilton 3240, New Zealand \\ †Biosciences Research Division, Department of Environment and Primary Industries Victoria, Bundoora, VIC 3083, Australia \\ $\ddagger$ Dairy Futures Cooperative Research Centre, Bundoora, VIC 3083, Australia \\ §Livestock Improvement Corporation, Hamilton 3240, New Zealand \\ \#Future Farming Systems Research Division, Department of Environment and Primary Industries, Victoria, Ellinbank, VIC 3820, Australia \\ IIFuture Farming Systems Research Division, Department of Environment and Primary Industries, Victoria, Tatura, VIC 3616, Australia
}

\begin{abstract}
Residual feed intake (RFI), as a measure of feed conversion during growth, was estimated for around 2,000 growing Holstein-Friesian heifer calves aged 6 to 9 mo in New Zealand and Australia, and individuals from the most and least efficient deciles (low and high RFI phenotypes) were retained. These animals (78 New Zealand cows, 105 Australian cows) were reevaluated during their first lactation to determine if divergence for RFI observed during growth was maintained during lactation. Mean daily body weight (BW) gain during assessment as calves had been 0.86 and $1.15 \mathrm{~kg}$ for the respective countries, and the divergence in RFI between most and least efficient deciles for growth was $21 \%$ (1.39 and $1.42 \mathrm{~kg}$ of dry matter, for New Zealand and Australia, respectively). At the commencement of evaluation during lactation, the cows were aged 26 to 29 mo. All were fed alfalfa and grass cubes; it was the sole diet in New Zealand, whereas $6 \mathrm{~kg}$ of crushed wheat/d was also fed in Australia. Measurements of RFI during lactation occurred for 34 to $37 \mathrm{~d}$ with measurements of milk production (daily), milk composition (2 to 3 times per week), BW and BW change (1 to 3 times per week), as well as body condition score (BCS). Daily milk production averaged $13.8 \mathrm{~kg}$ for New Zealand cows and $20.0 \mathrm{~kg}$ in Australia. No statistically significant differences were observed between calf RFI decile groups for dry matter intake, milk production, BW change, or BCS; however a significant difference was noted between groups for lactating RFI. Residual feed intake was about 3\% lower for lactating cows identified as most efficient as growing calves, and no negative effects on production were observed. These results support the
\end{abstract}

Received July 4, 2013.

Accepted November 1, 2013.

${ }^{1}$ Corresponding author: kevin.macdonald@dairynz.co.nz hypothesis that calves divergent for RFI during growth are also divergent for RFI when lactating. The causes for this reduced divergence need to be investigated to ensure that genetic selection programs based on low RFI (better efficiency) are robust.

Key words: feed efficiency, residual feed intake, growing heifer, lactating heifer

\section{INTRODUCTION}

Global demand for dairy products is increasing (FAO, 2009) and, at the same time, available land for production of animal feed is declining. Mechanisms that can increase efficiency of feed used for dairying, either by improvements in farm systems or directly by the animal, are needed. Residual feed intake (RFI; the difference between actual and predicted intakes) is perhaps the most common method of comparing animals for feed efficiency; although Cruz et al. (2010) suggested it is not ideal, as the precise mechanism that confers variation in efficiency is blurred and different mechanisms could contribute more for one animal and less for another. Nevertheless, divergence in RFI in farm livestock is well established, especially for growth in beef cattle (e.g., Basarab et al., 2003; Castro Bulle et al., 2007; Herd and Arthur, 2009) and more recently in young growing Holstein-Friesian heifers (Williams et al., 2011; Waghorn et al., 2012). The latter trials with dairy heifers were designed to develop genomic predictions of the RFI trait (Pryce et al., 2012) and it was hypothesized that divergence in RFI for growth would also predict RFI during lactation. This hypothesis was based on 2 premises: that RFI has a biochemical basis (which could include rumen function; Waghorn and Dewhurst, 2007), which would be applicable to animals irrespective of age and physiological status, and that RFI applies to energy expenditure for maintenance and 
production. Waghorn et al. (2012) calculated that only $28 \%$ of ME intake (MEI) was incorporated into milk over the 7-yr lifetime of Holstein-Friesian cows' grazing pasture. The extent to which energy is partitioned between maintenance and production will differ between farm systems, but in dairy cows maintenance requirements are always large and with pasture diets usually exceed $50 \%$ of MEI.

Implementing measurements of RFI in pasture-based systems is difficult, as intakes of grazing animals cannot be measured accurately. This has focused research toward identification of genetic markers for the trait as a means to identify animals divergent for RFI. Nearly 2,000 growing Holstein-Friesian heifers (aged 6 to 9 mo) were phenotyped for RFI in New Zealand (NZ; Waghorn et al., 2012) and Australia (AUST; Williams et al., 2011) while being fed alfalfa cubes as a sole diet.

The hypothesis tested in the current study was that lactating, primiparous cows, previously identified as being divergent in RFI as growing calves (Williams et al., 2011; Waghorn et al., 2012), would still differ in RFI during lactation. Herein we test this hypothesis at a phenotypic level, by those cows with high and low RFI as calves for their RFI in first lactation. If confirmed, the genomic prediction of RFI in growing heifers (Pryce et al., 2012) could be used to select breeding animals with higher genetic merit for RFI. Further validation focusing on the accuracy of genomic predictions in lactating cows is reported in a companion paper by Davis et al. (2014).

\section{MATERIALS AND METHODS}

A brief overview of methods associated with RFI determination in the calves is presented here. Full details have been given by Waghorn et al. (2012) and Williams et al. (2011) for the NZ and AUST research, respectively.

\section{Young Growing Heifer Calves}

Measurements of RFI in growing heifers commenced in 2008, with 1,049 calves evaluated in NZ and 903 in AUST. Calves, aged $210 \pm 24.5$ and $220 \pm 18 \mathrm{~d}( \pm$ SD) in NZ and AUST, respectively, underwent a 49- to 70-d measurement period to determine RFI for growth. They were fed alfalfa (Medicago sativa) hay compressed into cubes as their sole diet. Individual DMI were measured using automated feed intake systems (Gallagher Animal Management Systems, Hamilton, New Zealand) and BW was recorded frequently. Residual feed intake was estimated as the residual after multiple regression of DMI on ADG $(\mathrm{kg} / \mathrm{d})$ and mean $\mathrm{BW}$ at the trial midpoint for all calves in each cohort (Williams et al., 2011; Waghorn et al., 2012). The AUST analysis included a model adjustment for age and farm of origin (Williams et al., 2011).

\section{Lactating Heifer Assessments}

The $10 \%$ most and least efficient calves based on RFI were retained and bred to calve around 24 mo of age. These animals were reevaluated for RFI during their first lactation ( $\mathrm{n}=78$ and 105 in NZ and AUST, respectively).

The NZ heifers were born in July and August 2008 and evaluated for RFI during growth in January to May 2009. Evaluation during lactation was in 2 batches, commencing September 28, 2010 for batch $1(\mathrm{n}=38)$ and November 9, 2010 for batch $2(\mathrm{n}=40$; Table 1$)$. The 78 calves selected for evaluation during lactation in NZ comprised 39 with low RFI (efficient) and 39 with high RFI (inefficient) for growth at 6 to 9 mo of age. Average DMI of these calves were $7.61 \mathrm{~kg} / \mathrm{d}$, and low and high RFI groups diverged from this mean by -0.71 $( \pm 0.26)$ and $0.68( \pm 0.25) \mathrm{kg}$ of $\mathrm{DM} / \mathrm{d}$, respectively; ADG was $0.86 \mathrm{~kg} / \mathrm{d}$ for both groups. Mean birth date for each batch in NZ differed by $3 \mathrm{wk}$, and animals were 790 and $832 \mathrm{~d}$ for batches 1 and 2, respectively, at the commencement of the measurement periods to determine RFI $(812 \pm 25.2 \mathrm{~d})$.

The heifers used in the AUST evaluation were born in July to September 2008 (cohort 1) and July to September 2009 (cohort 3), and evaluated for RFI during growth in January to March 2010 and November 2011, respectively. Cohort 2 cows were autumn-born calves and did not fit into the farming practice of the herd where the cow experiment was performed. Therefore, for the purposes of this paper, the AUST cohorts 1 and 3 will be referred to as batch 1 and 2 for AUST. The 105 calves selected for evaluation in AUST included 50 low and 55 high RFI and their average DMI was 8.3 $\mathrm{kg} / \mathrm{d}$. The divergence was $-0.67( \pm 0.24)$ and $0.67( \pm$ $0.26) \mathrm{kg}$ for the low and high RFI groups, respectively; ADG was $1.08 \mathrm{~kg} / \mathrm{d}$ for both groups. Evaluation of these animals during their first lactation occurred in February 2011 for batch $1(\mathrm{n}=54)$ and in November 2011 for batch $2(\mathrm{n}=51$; Table 1$)$. Each group comprised similar numbers of individuals with similar divergence for RFI. The evaluation of AUST heifers commenced at $938 \pm 12 \mathrm{~d}$ of age for batch 1 and $812 \pm 18 \mathrm{~d}$ for batch 3 , with an overall average $875 \mathrm{~d}$.

Mean DIM at the start of each measurement period was 75 and 101 for batch 1 and 2 of NZ cows and 208 and 92 for batch 1 and 2 of AUST cows. The NZ trial was approved by the Ruakura Animal Ethics Committee (Hamilton, New Zealand) and the AUST trial was approved by the DPI Agricultural Research and Exten- 
Table 1. Dry matter intake, milk, fat, protein and lactose yields, BW, BW change (BWA), average BCS, calculated ME intake (MJ intake), requirements for maintenance (MJ Maint), milk production (MJ Prod), and activity (MJ Act) for New Zealand and Australian cows selected for divergence in residual feed intake as 6- to 9-mo-old calves, during trials to measure residual feed intake in their first lactation

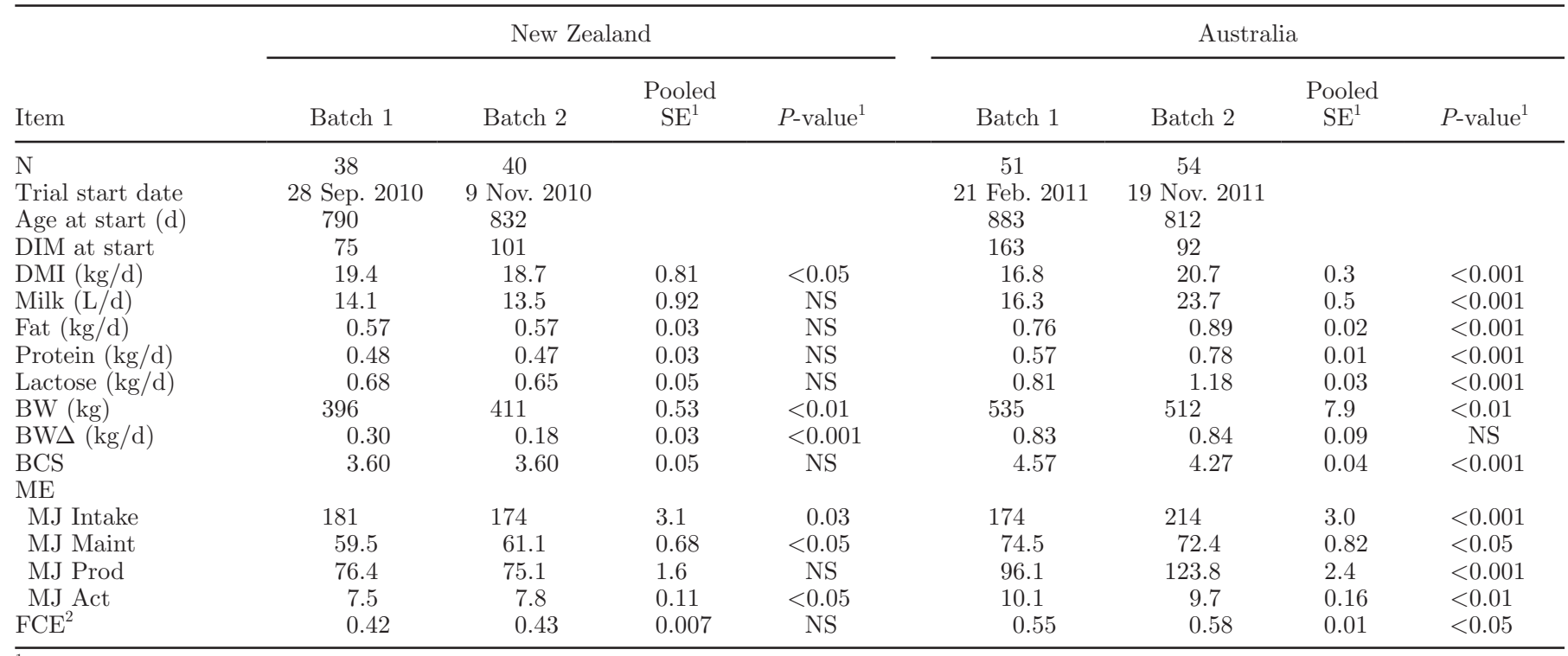

${ }^{1}$ Pooled SE and $P$-values are given relative to each country.

${ }^{2} \mathrm{FCE}=$ feed conversion efficiency.

sion Animal Ethics Committee (Hamilton, Victoria, Australia).

\section{Feeding and Facilities}

Feed was always available during all cow evaluations in NZ and for cows from batch 2 in AUST. Individual intakes were determined using electronic monitoring of load cells under feed bins (Gallagher Animal Management Systems, Hamilton, New Zealand) and electronic identification of individual animals. Individual DMI were measured over $35 \mathrm{~d}$ in the NZ studies and for 32 and $37 \mathrm{~d}$ for batches 1 and 2, respectively, in the AUST studies.

The cubes fed to lactating cows in NZ comprised a 50:50 mix (DM basis) of alfalfa and pasture (predominantly ryegrass; Lolium perenne L.) hay compressed into $30-\mathrm{mm}$ cubes with approximately $85 \% \mathrm{DM}$. They were manufactured by Multicube Ltd. (Yarrawonga, Victoria, Australia) and contained $17.5 \% \mathrm{CP}$ and $50.3 \%$ amylase-treated NDF (aNDF). Australian batch 1 cows were offered alfalfa hay that was chopped in a mixer wagon (Richard Keenan and Co. Ltd., Model K160, Co. Carlow, Ireland) to a fiber length of approximately $5 \mathrm{~cm}$. Australian batch 2 cows were offered alfalfa cubes from the same manufacturer as NZ with $22.7 \% \mathrm{CP}$ and $37.3 \%$ NDF.

Each bin was shared in NZ, as 9 to 10 cows had access to 7 feed bins and allowed ample space to lie and walk. Water and trace mineralized salt (Dominion
Salt Ltd., Mount Maunganui, New Zealand) were freely available.

For batch 2 in AUST, 54 cows had access to 30 bins. Animals were not restrained and had ample space to walk and lie down. Measurements for batch 1 in AUST were made from a single bin allocated to each cow. Cows were offered feed for $3 \mathrm{~h}$ after both AM and PM milking, after which they were held on a dry lot area without feed, but with water available ad libitum. Both AUST batches consumed an additional $6.2 \pm 0.25 \mathrm{~kg}$ of $\mathrm{DM} / \mathrm{d}$ of crushed wheat (Table 1 ) fed in 2 portions at milking, in line with normal feeding practice.

Samples of cubes were collected weekly. Subsamples dried at $100^{\circ} \mathrm{C}$ for $24 \mathrm{~h}$ were used to determine DM content, and subsamples dried at $60^{\circ} \mathrm{C}$ for $72 \mathrm{~h}$ were analyzed after grinding by near infrared spectrometry at FeedTech (AgResearch, Palmerston North, New Zealand) or Feed Test/Agrifood technology (Werribee, Victoria, Australia) to estimate CP, aNDF, and ME. Samples of crushed wheat and alfalfa hay were analyzed by near infrared at the Dairy One Forage Laboratory (Ithaca, NY). Data describing DM and ME intakes for each group tested are given in Table 1.

The alfalfa and pasture cubes fed in NZ contained 9.3 MJ of ME $/ \mathrm{kg}$ of DM, with $16.4 \% \mathrm{CP}$ and $50.3 \%$ aNDF in the DM and those fed to batch 2 in AUST contained $10.2 \mathrm{MJ}$ of $\mathrm{ME} / \mathrm{kg}$ of $\mathrm{DM}$, with $22.7 \% \mathrm{CP}$ and $37.3 \%$ NDF. The hay fed to batch 1 cows had 8.7 MJ of ME/ $\mathrm{kg}$ of DM, with $18.2 \% \mathrm{CP}$ and $46.3 \% \mathrm{NDF}$ in the DM. The crushed wheat fed to batches 1 and 2 contained 
13.8 and $13.8 \mathrm{MJ}$ of ME, 13.1 and $13.9 \% \mathrm{CP}$, and 10.2 and $14.3 \%$ aNDF, respectively.

\section{Measurements}

Milk yields were measured using similar facilities and protocols in both countries, with in-line meters and milking at about 0700 and $1600 \mathrm{~h}$ each day. The NZ milking system was from Westphalia Surge (GEA Farm Technologies GmbH, Bönen, Germany), and AM and PM composite cow samples were collected 3 times weekly to determine fat, protein, casein, lactose, and total solids by infrared milk analyzer (FT120, Foss Electric, Hillerød, Denmark). In AUST, a DeLaval Alpro milk metering system (DeLaval International, Tumba, Sweden) was used to measure production; fat, protein, and lactose concentrations were determined 3 $\mathrm{d} /$ wk from separate analyses of consecutive PM and AM milk samples using an infrared analyzer (Model 2000, Bentley Instruments, Chaska, MN).

In NZ, cow BW was measured using manual scales (Gallagher Smart Scale 500) 3 times per week during the trial and twice weekly for 4 wk before and after the intake measurements. In AUST, BW was measured once daily after morning milking (DeLaval Automatic weigh system AWS100, Tumba, Sweden).

Cow BCS was assessed weekly. In NZ, a 10-point scale was used, where 1 is emaciated and 10 is obese (Roche et al., 2004). In AUST, BCS was based on an 8-point scale (Earle, 1976), and values were converted to the 10-point scale using the formula of Roche et al. (2004) to allow comparison.

\section{Data Analyses During Lactation}

Analyses to determine divergence in RFI during calf growth have been described by Williams et al. (2011) and Waghorn et al. (2012). Analyses during lactation followed a similar approach. Means of daily DMI, milk, yields of fat, lactose, and protein, as well as BW and BCS were calculated within each experimental period. Daily change in BW was calculated as the linear regression of BW over $4 \mathrm{wk}$ pre- and posttrial in NZ. This period was chosen as a means to avoid transitory effects of additional gastrointestinal tract fill on BW observed to occur when cows accustomed to grazing fresh pasture were offered cubes ad libitum. For AUST animals, changes in BW were calculated directly from the measured period. Data points $>3$ SD from the mean for an individual cow were removed before the analysis. This accounted for only $0.67 \%$ of the total data.

To determine if growing heifer calves that were divergent for RFI were also divergent during their first lactation, RFI for the lactating cows was calculated as the residual from multiple regression as in the following formulae and was calculated in 2 ways:

1. RFI of each individual was calculated by fitting the following regression equation within batches (NZ 1, 2; AUST 1, 2) using

$$
\begin{aligned}
\mathrm{DMI}= & \text { fat yield }+ \text { protein yield }+ \text { lactose yield } \\
& +\mathrm{BW}^{0.75}+\mathrm{BW} \Delta+\mathrm{BCS}+\mathrm{RFI},
\end{aligned}
$$

where $\mathrm{BW}^{0.75}$ represents metabolic BW; and

2. by calculating the difference between ME intake and predicted ME requirements for maintenance, activity, and lactation (RFIMJ). The ME requirements for milk, maintenance, and activity were calculated using equations of Heard et al. (2011) and based on definitions of the Primary Industries Standing Committee (2007).

Megajoules of dry matter intake (MJDMI) was the average ME intake per day, calculated by multiplying the average DMI of dietary components by their ME of megajoules per kilogram of DM. MJDMI $=\mathrm{ME}_{\mathrm{m}}+$ $\mathrm{ME}_{1}+\mathrm{ME}_{\mathrm{a}}$ and $\mathrm{ME}_{\mathrm{m}}, \mathrm{ME}_{\mathrm{l}}$, and $\mathrm{ME}_{\mathrm{a}}$ are the energy requirements for maintenance, lactation, and activity, respectively. From CSIRO (2007) and Heard et al. (2011, Appendix 1),

$$
\begin{aligned}
\mathrm{ME}_{\mathrm{m}}(\mathrm{MJ} / \mathrm{d})= & \mathrm{kM}\left[0.28 \mathrm{BW}^{0.75} \exp (-0.03 \mathrm{~A})\right] / \\
& \mathrm{K}_{\mathrm{m}}+0.1 \mathrm{ME}_{\mathrm{l}}
\end{aligned}
$$

where $\mathrm{k}=1.4$ for Bos taurus animals; $\mathrm{M}=1+0.23$ $\times$ proportion of digestible energy from milk; $\mathrm{A}=$ age in years (2); $\mathrm{K}_{\mathrm{m}}=$ net efficiency of the use of ME for maintenance, $\mathrm{K}_{\mathrm{m}}=0.02 \times$ average $\mathrm{ME}$ of diet (see below) +0.5 ; and $\mathrm{ME}_{1}=$ amount of dietary $\mathrm{ME}(\mathrm{MJ})$ being used directly for lactation, where $\mathrm{ME}_{1}=0.0381$ $\times$ fat yield $+0.0245 \times$ protein yield $+0.0165 \times$ lactose yield.

$$
\text { Finally, } \mathrm{ME}_{\mathrm{a}}=\frac{0.0026 \times \text { distance } \times \mathrm{BW}}{\mathrm{km}} \text {. }
$$

A measure of gross feed conversion efficiency (FCE) was calculated using the calculated energy content of total energy intake.

\section{Statistical Analyses}

All statistical analyses were performed in $\mathrm{R}$ (version 2.15.2; The R Foundation for Statistical Computing; http://www.r-project.org). Estimates of lactating cow RFI for the efficient group were contrasted to the inefficient group using a linear model following adjustment for DIM, and batch BCS was included as a covariate 
in the model so that potential differences between the 2 groups that were associated with differences in body tissue mobilization, rather than efficiency, could be explained and removed from the RFI phenotype. That is, we attempted to avoid identifying animals as efficient (eating less than expected) because they were actually mobilizing body tissue reserves. The analyses were also repeated within country (omitting country from the model).

A similar model was used including DIM, batch to estimate milk production, BW, BCS, and energy partitioning for each efficiency group. Student's 2-sample $t$-tests were used to compare differences between the RFI of lactating cows based of the 2 groups (efficient and inefficient growing heifers), within countries, and in the combined data set.

\section{RESULTS}

Days in milk, BW, and trial dates for each batch (within country) were similar at trial commencement for all groups, except batch 1 (Table 1). Cows in batch 1 (AUST) were older and had a greater DIM than the other groups. The AUST Holstein-Friesian cows were about $100 \mathrm{~kg}$ heavier than the phenotype used in NZ. Whereas statistically significant differences were evident between batches of NZ cows for DMI, BW, and $\mathrm{BW} \Delta$, most production indices were similar (Table 1). In contrast, intakes and production were significantly different between batches 1 and 2 of the AUST cows (Table 1).

The AUST cows had a similar overall mean DMI $(18.8 \mathrm{~kg} / \mathrm{d})$ to the NZ cows $(19.1 \mathrm{~kg} / \mathrm{d} ; P=0.54)$, but higher overall mean milk production (20.0 vs. 13.3 $\mathrm{kg} / \mathrm{d}$ ) and a higher overall mean daily $\mathrm{BW}$ gain (Table 1). Estimated ME intake averaged 178 (NZ) and 194 $\mathrm{MJ} / \mathrm{d}$ (AUST), and FCE for milk (MJ of milk/MJ of intake) was greater for AUST than NZ cows (0.57 vs. $0.43 ; P<0.001)$.

Regression analysis of data from lactating cows identified as efficient (low RFI) as growing calves, compared with those that were inefficient as calves (high RFI), showed differences in DMI of 0.48 and $0.43 \mathrm{~kg} / \mathrm{d}$ for $\mathrm{NZ}$ and AUST cows between the efficiency groups. The overall pooled difference in DMI from pooled data was $0.46 \mathrm{~kg} / \mathrm{d}$ between the low- and high-RFI groups (Table $2)$. The SD of RFI were $1.0,1.10$, and $1.05 \mathrm{~kg} / \mathrm{d}$ for NZ, AUST, and pooled data, respectively. The difference in RFI between groups was significant for pooled data $(P<0.002)$ and within each country $(P<0.05)$, demonstrating the increased power obtained by combining data sets (Table 2). Figure 1 demonstrates the distribution of RFI for cows within each RFI grouping (efficient or inefficient).
Very similar results were observed for RFI calculated on an ME basis. When data were combined, those lactating cows determined to be efficient as growing calves used 4.3 MJ less energy per day ( $0.46 \mathrm{~kg}$ of DM/d) than those determined to be inefficient $(P<0.002$; Table 2$)$. Divergence was also significant within each country $(P$ $<0.05$ ). No other differences were observed (Table 2 ) in pooled data between groups except for a tendency $(P$ $<0.1$ ) for efficient cows to be heavier than inefficient cows. In New Zealand, FCE (MJ energy partitioned to lactation relative to energy intake) was greater in efficient animals $(P<0.05$; Table 2$)$.

\section{DISCUSSION}

The measurements presented here have demonstrated that divergence in RFI for growth was retained during lactation, but to a reduced extent. Where RFI has been measured in growing beef cattle, divergence between the $10 \%$ most and least efficient groups has been about $20 \%$ (e.g., Basarab et al., 2003; Carstens and Tedeschi, 2006; Lawrence et al., 2011). The difference between divergent groups of growing Holstein-Friesian heifers (top and bottom $10 \%$ for RFI) was 20.5 and $21.6 \%$ [NZ (Waghorn et al., 2012) and AUST (Williams et al., 2011), respectively].

Divergence for RFI during growth as calves, between the efficient and inefficient animals retained for this experiment, was $1.39 \mathrm{~kg}$ of $\mathrm{DM} / \mathrm{d}$ (mean DMI $=7.61$ $\mathrm{kg} / \mathrm{d}$ ) in NZ and $1.34 \mathrm{~kg} / \mathrm{d}$ (mean DMI $=8.3 \mathrm{~kg} / \mathrm{d}$ ) in AUST (i.e., 16 and 18\%, respectively). During lactation, the difference between groups declined to 0.48 and $0.43 \mathrm{~kg} / \mathrm{d}$ in NZ and AUST, respectively (i.e., only $2.4 \%$ of total DMI).

Substantial overlap exists between the calf-selected efficiency groups (Figure 1) during lactation, suggesting that the RFI characteristic as a calf was not fully retained in all individuals. Divergent groups $(10 \%$ most and least efficient) were selected from growing calves databased on a single measurement period. Circumstances precluded any measure of repeatability. Changes in RFI with time and feed type have been demonstrated by Kelly et al. (2010). They reported a repeatability of 0.62 for RFI in Limousin $\times$ Friesian heifers evaluated when fed grower and finisher diets at 8 to 11 and 16 to 20 mo of age, respectively. Durunna et al. (2011) also reported substantial reranking for RFI between sequential 10-wk measurement periods starting from $7 \mathrm{mo}$ of age in steers. Reranking occurred even when animals were offered the same feed and was greater if a dietary change was introduced. After $3 \mathrm{y}$ of measurements of beef heifers, Durunna et al. (2012) reported only 49\% maintained their RFI ranking between consecutive 10 -wk periods. They suggested 
Table 2. Calculated differences between groups of lactating cows previously identified as efficient (low residual feed intake; RFI) and inefficient (high RFI) as growing calves (6 to 9 mo of age $)^{1}$

\begin{tabular}{|c|c|c|c|c|c|c|c|c|c|}
\hline \multirow[b]{2}{*}{ Item } & \multicolumn{3}{|c|}{ New Zealand ${ }^{2}$} & \multicolumn{3}{|c|}{ Australia $^{2}$} & \multicolumn{3}{|c|}{ Pooled $^{3}$} \\
\hline & Difference & $\begin{array}{c}\text { Pooled } \\
\text { SE }\end{array}$ & $P$-value & Difference & $\begin{array}{c}\text { Pooled } \\
\text { SE }\end{array}$ & $P$-value & Difference & $\begin{array}{c}\text { Pooled } \\
\text { SE }\end{array}$ & $P$-value \\
\hline $\mathrm{RFI}$ (kg of DMI/d) & -0.48 & 0.21 & $<0.05$ & -0.43 & 0.20 & $<0.05$ & -0.46 & 0.15 & 0.002 \\
\hline RFIMJ (MJ/d) & -4.7 & 2.0 & $<0.05$ & -3.9 & 1.9 & $<0.05$ & -4.3 & 1.4 & 0.002 \\
\hline \multicolumn{10}{|l|}{ Production parameters } \\
\hline Fat $(\mathrm{kg} / \mathrm{d})$ & 0.00 & 0.01 & NS & 0.00 & 0.02 & NS & 0.00 & 0.01 & NS \\
\hline Protein $(\mathrm{kg} / \mathrm{d})$ & 0.02 & 0.01 & NS & 0.00 & 0.01 & NS & 0.00 & 0.01 & NS \\
\hline Lactose $(\mathrm{kg} / \mathrm{d})$ & 0.03 & 0.02 & NS & -0.02 & 0.03 & NS & 0.00 & 0.02 & NS \\
\hline BW (kg) & 4.3 & 5.8 & NS & 14.1 & 7.9 & NS & 10.3 & 5.2 & $<0.1$ \\
\hline BW change (kg/d) & 0.03 & 0.03 & NS & 0.01 & 0.10 & NS & 0.02 & 0.05 & NS \\
\hline BCS & 0.00 & 0.05 & NS & 0.02 & 0.08 & NS & 0.00 & 0.05 & NS \\
\hline \multicolumn{10}{|c|}{ Calculated ME values ${ }^{4}(/ d)$} \\
\hline
\end{tabular}

${ }^{1}$ Divergence in RFI and predicted ME requirements for maintenance, activity, and lactation (RFIMJ) and production parameters and calculated $\mathrm{ME}$ values for intake and production.

${ }^{2}$ Data from 78 animals (New Zealand) and 105 animals (Australia) are pooled within country.

${ }^{3}$ Data from both countries pooled.

${ }^{4}$ Metabolizable energy requirements for maintenance (MJ Maint), milk production (MJ Prod), and activity (MJ Act).

${ }^{5} \mathrm{FCE}=$ feed conversion efficiency.

that "reranking may be more serious amongst the more divergent animals." It is interesting to note that divergences of 0.94 and $0.90 \mathrm{~kg}$ of $\mathrm{DM} / \mathrm{d}$ were reported for first and second measurement periods and, despite reranking, divergence between groups remained similar (Durunna et al. 2012).

Differences in activity between RFI groups is a possible explanation for the efficiency of feed use. The activity measure used in the RFI calculations (method 2) was based on BW and activity. The activity levels used to predict RFI for the second method were determined according to standard equations and not measured directly; thus, the possibility remains that the differences in observed RFI are related to different activity levels of the animals. No measurements were made that could refute this, but in growing Holstein heifers (some of which were part of the current study), Lin et al. (2013) and Green et al. (2013) both reported an association between RFI with 2 feeding behavior traits - feeding duration (genetic association) and eating rate (phenotypic association) - so heifers that ate more slowly had improved feed efficiency.

\section{Causes of Diminished Divergence}

If selection for RFI is to have commercial value by identifying individuals that need less than the average amount of feed, it is essential that some level of divergence is maintained. Reranking or changes in the extent of divergence will lessen the commercial value of this trait. If those parameters responsible for divergence (e.g., digestion, metabolism, behavior, and so on) were known, selection might be improved. Herd and Arthur (2009) reviewed aspects of metabolism, digestion, and behavior that may contribute to divergence for RFI and metabolic efficiency. The method of calculation suggests that divergence can only be associated with energy that is not partitioned toward product (i.e., energy used for maintenance, growth, and other metabolic functions). In the cows evaluated in the present study, a higher percentage of dietary ME was retained in milk (25 and 34\% for NZ and AUST, respectively) compared with BW gain (19\% in both countries; Primary Industries Standing Committee, 2007). For beef cattle, Cruz et al. (2010) suggested that RFI is a poor indicator of commercial value relative to other measures, such as intake, production, and gross efficiency, as a given mechanism could contribute more for one animal and less for another.

The high percentage of feed energy retained in milk versus BW gain could account for some of the reduced divergence between growth and lactation phases, because a lower percentage of dietary energy will be subject to variations in efficiency. Another factor that 


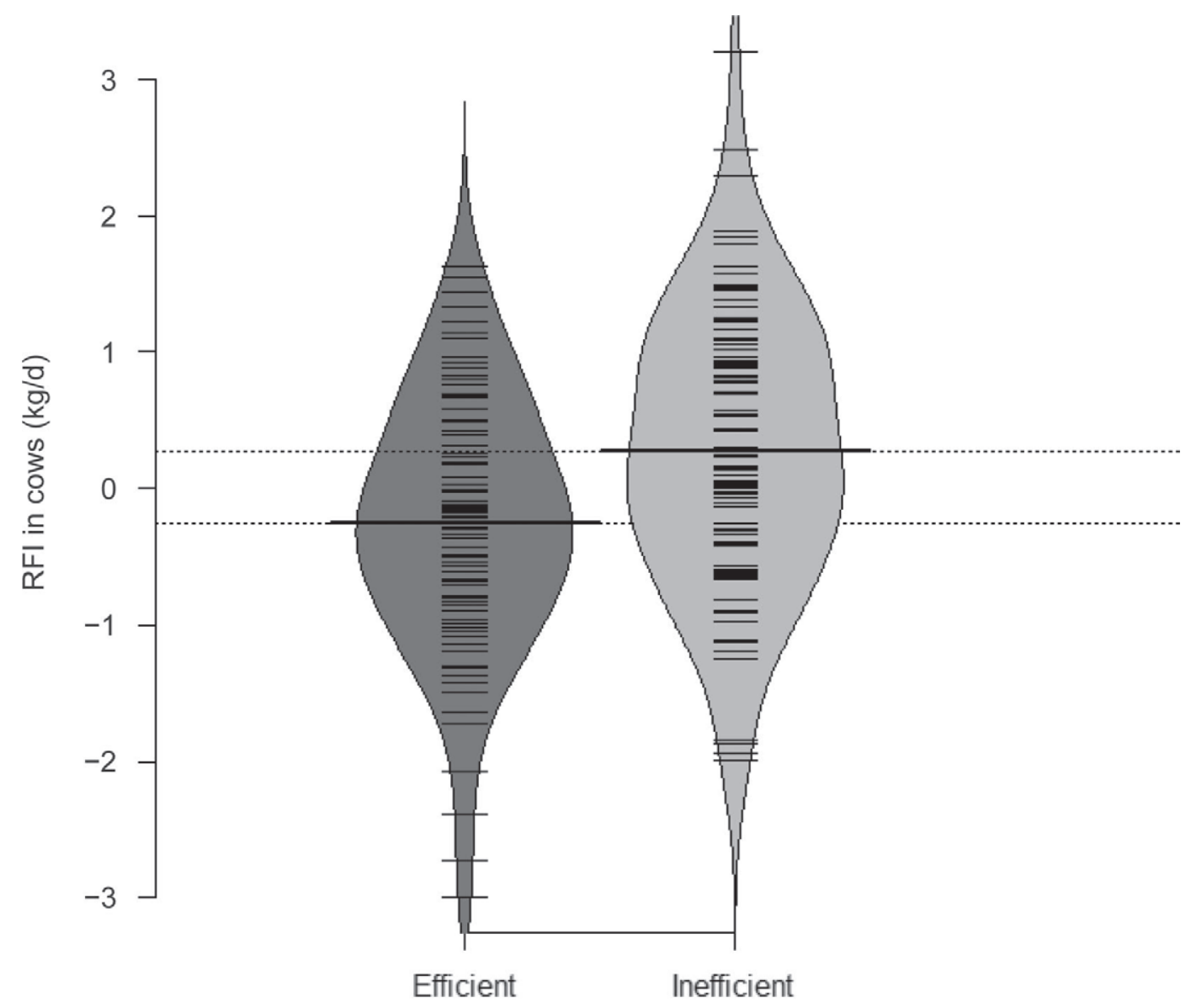

RFl in calves

Figure 1. Divergence in residual feed intake (RFI) of first parity cows from a combined data set from New Zealand and Australia, where the cows were selected to be extreme (top and bottom 10\%) for RFI as 6- to 9-mo-old calves. The short horizontal lines represent data points for individual cows and longer solid lines are the means for each RFI group.

could contribute to the reduction in divergence during lactation is whole body (tissue) protein synthesis because it accounts for 10 to $15 \%$ of energy expenditure (Baldwin, 1995) and declines with age (Attaix et al., 2005). However, the decline is minor after about 30 wk of age (when the evaluation of RFI for growth took place), and the summary by Attaix et al. (2005) demonstrates an increased turnover associated with increased intakes (as in lactation) due to increased visceral and also muscle fractional synthesis rates. Variation in protein synthesis may have contributed to reduced divergence during lactation, but supportive experimental data are lacking. Divergence in postpartum tissue (adipose and muscle) tissue mobilization and synthesis could also affect the efficiency of feed utilization because of inefficiencies in energy retention during both processes. No significant differences in BCS were observed between groups during lactation in the study reported here, so the influences of this on measures of divergence are likely to be small, at the least, controlled by the experimental design.

Divergence may also be affected by differences in heat production or digestibility. Heat production is a summation of biochemical inefficiencies, and although mitochondrial activity plays a central role in energetics, Bottje and Carstens (2009) were unable to identify consistent relationships with RFI, and no inferences can be drawn regarding effects of age on divergence. The higher intakes of the lactating cows evaluated in the current study, relative to intakes as calves (2.4-3.0 vs. $\left.1.8 \times \mathrm{ME}_{\mathrm{m}}\right)$, could also have affected nutrient supply if digestibility had declined in response to increasing intake (e.g., Tyrrell and Moe, 1975). The divergence of intakes when the animals used in the current study were calves $(1.37 \mathrm{~kg} / \mathrm{d} ; 17 \%)$ may have resulted in a longer rumen retention time (and higher digestion) in the efficient individuals because their intakes were lower than for inefficient calves, but this was not measured. 
During lactation the differences in intakes of the divergent groups were minor, so rumen function was unlikely to be affected by RFI, especially as recent reports have suggested similar digestibilities in cows with high and low RFI (Herd and Arthur, 2009; Rius et al., 2012).

Reasons for the reduced divergence, other than the lower proportion of MEI used for maintenance and net synthesis in lactating cows, are speculative. The low repeatability in this and other studies (e.g., Kelly et al., 2010; Durunna et al., 2011, 2012) suggests the estimates of heritability for RFI are specific to the time of measurement. Heritabilities of 0.38 (NZ) and 0.22 (AUST) were calculated from the heifer growth study (Pryce et al., 2012). Likewise, Arthur et al. (2010) summarized values for heritability of RFI ranging from 0.16 to 0.39 after reviewing studies with nearly 9,000 growing beef cattle since the year 2000. Reranking and low repeatability for RFI, and reduced divergence in the same animals evaluated during growth and lactation as reported herein, suggests a need for caution when interpreting results. It is essential that the metabolic and physiological processes that contribute to efficiency and divergence in RFI are identified to define a trait that is sufficiently robust to be incorporated into animal selection.

\section{Diet and Country Effects}

Diet and products of digestion have been postulated as possible causes of divergence in RFI (Waghorn and Dewhurst, 2007). Diet is likely to affect changes in the rumen microflora, especially if forage is substituted with a high-grain diet. Rius et al. (2012) reported minor differences in the rumen microflora of cows with divergent RFI fed fresh, high-quality pasture, with some interactions between RFI, diet, and rumen microflora. Carberry et al. (2012) reported larger differences in rumen microflora when divergent cattle were fed a silage diet than when fed a concentrate-based diet; but the opposite was reported in a similar evaluation of bacterial populations by Hernandez-Sanabria et al. (2012). Interestingly, divergence in RFI was maintained in the AUST cows when fed $6 \mathrm{~kg} / \mathrm{d}$ of crushed wheat in addition to roughage, even though selection as calves was based on a dried alfalfa diet (Williams et al., 2011). In the measurements presented herein, the grain was only one-third of total dietary DMI, and the data do not suggest interactions between RFI and diet. Selection for divergent RFI as calves was maintained in lactating cows, even when diets contained an appreciable proportion of grain.

Cow intakes and production were similar for both batches from NZ, whereas differences between the batches (AUST) were mainly due to the differences in
DIM of cows (208 and $92 \mathrm{~d}$, respectively; Table 1); this was a consequence of facility availability. Nevertheless, whereas this compounded differences between batches along with differences in diet and feeding regimen, similar levels of divergence were evident for both batches.

\section{CONCLUSIONS}

In the trials reported in the current study, divergence for RFI as measured in growing calves was retained, but at a much reduced level when RFI was measured when the same animals were lactating $(2.4 \%$ as lactating cows vs. $17 \%$ as growing calves). Although different feeding regimens were used for the lactating cows (alfalfa and pasture cubes for NZ and alfalfa cubes and grain for AUST), similar results were observed. Intake, milk production, milk composition, and BW changes were similar between divergent groups, confirming the independence of RFI, relative to production. Methods to identify and select more efficient animals would benefit from a better understanding of the underlying physiological causes of divergence. This may also inform about reported changes in RFI when repeat measures are reported and the relationships between measures are estimated during growth and lactation.

\section{ACKNOWLEDGMENTS}

The authors associated with DairyNZ and Livestock Improvement Corporation (LIC) thank the Ministry of Business, Industry and Employment (formerly Foundation for Research, Science and Technology; Wellington, New Zealand), New Zealand dairy farmers through DairyNZ Inc. (Hamilton, New Zealand), LIC (Hamilton, New Zealand), and Trade and Enterprise (Auckland, New Zealand) for funding, the LIC calf procurement team led by Katie Eketone and Jack Hooper, and the DairyNZ technical and farm teams at Hawera (New Zealand) for managing the experiments. The authors associated with the Department of Environment and Primary Industries thank the Gardiner Foundation (Melbourne, Australia), Dairy Futures CRC (Melbourne, Australia), and the Department of Environment and Primary Industries (Victoria, Australia) for funding and the technical groups at Rutherglen, Tatura, and Ellinbank (Victoria, Australia) for managing the experiments.

\section{REFERENCES}

Arthur, P. F., R. M. Herd, and J. A. Basarab. 2010. The role of cattle genetically efficient in feed utilisation in an Australian carbon trading environment. Aust. Farm Bus. Manag. J. 7:5-13.

Attaix, D., D. Remond, and I. C. Savary-Auzeloux. 2005 Protein metabolism and turnover. Pages 373-398 in Quantitative Aspects of 
Ruminant Metabolism. 2nd ed. J. Dijkstra, J. M. Forbes, and J. France, ed. CABI Publishing, Wallingford, UK.

Baldwin, R. L. 1995. Energy requirements for maintenance and production. Pages 148-188 in Modeling Ruminant Digestion and Metabolism. Chapman and Hall, London, UK.

Basarab, J. A., M. A. Price, J. L. Aalhus, E. K. Okine, W. M. Snelling, and K. L. Lyle. 2003. Residual feed intake and body composition in young growing cattle. Can. J. Anim. Sci. 83:189-204.

Bottje, W. G., and G. E. Carstens. 2009. Association of mitochondrial function and feed efficiency in poultry and livestock species. J. Anim. Sci. 87:E48-E63.

Carberry, C. A., D. A. Kenny, S. Han, M. S. McCabe, and S. M. Waters. 2012. Effect of phenotypic residual feed intake and dietary forage content on the rumen microbiological community of beef cattle. Appl. Environ. Microbiol. 78:4949-4958.

Carstens, G. E., and L. O. Tedeschi. 2006. Defining feed efficiency in beef cattle. Pages 12-21 in Beef Improvement Federation Conference, Choctaw, Mississippi. Accessed Dec. 1, 2013. http://msucares. com/livestock/beef/mbcia/bif2006proceedings.pdf\#page $=18$.

Castro Bulle, F. C. P., P. V. Paulino, A. C. Sanches, and R. D. Sainz. 2007. Growth, carcass quality, and protein and energy metabolism in beef cattle with different growth potentials and residual feed intakes. J. Anim. Sci. 85:928-936.

Cruz, G. D., J. A. Rodríguez-Sánchez, J. W. Oltjen, and R. D. Sainz. 2010. Performance, residual feed intake, digestibility, carcass traits, and performance of Angus-Hereford steers housed in individual or group pens. J. Anim. Sci. 88:324-329.

CSIRO. 2007. Nutrient Requirements of Domesticated Ruminants. CSIRO publishing, Melbourne, Australia.

Davis, S. R., K. A. Macdonald, G. C. Waghorn, and R. J. Spelman. 2014. Residual feed intake of lactating Holstein-Friesian cows predicted from high-density genotypes and phenotyping of growing heifers. J. Dairy Sci. 97:1436-1445.

Durunna, O. N., M. G. Colazo, D. J. Ambrose, D. McCartney, V. S. Baron, and J. A. Basarab. 2012. Evidence of residual feed intake reranking in crossbred replacement heifers. J. Anim. Sci. 90:734-741

Durunna, O. N., F. D. N. Mujibi, L. Goonewardene, E. K. Okine, J. A. Basarab, Z. Wang, and S. S. Moore. 2011. Feed efficiency differences and reranking in beef steer s fed grower and finisher diets. J. Anim. Sci. 89:158-167.

Earle, D. F. 1976. A guide to scoring dairy cow condition. J. Agric. (Victoria) 74:228-231.

FAO. 2009. Declaration of the World Summit on Food Security. Accessed Dec. 1, 2013. ftp://ftp.fao.org/docrep/fao/Meeting/018/ k6050e.pdf.

Green, T. C., J. G. Jago, K. A. Macdonald, and G. C. Waghorn. 2013. Relationships between residual feed intake, average daily gain and feeding behavior in growing dairy heifers. J. Dairy Sci. 96:3098-3107.

Heard, J. W., P. T. Doyle, S. A. Francis, M. H. Staines, and W. J. Wales. 2011. Calculating dry matter consumption of dairy herds in
Australia: The need to fully account for energy requirements and issues with estimating energy supply. Anim. Prod. Sci. 51:605614

Herd, R. M., and P. F. Arthur. 2009. Physiological basis for residual feed intake. J. Anim. Sci. 87:E64-E71.

Hernandez-Sanabria, E., L. A. Goonewardene, Z. Wang, O. N. Durunna, S. S. Moore, and L. L. Guan. 2012. Impact of feed efficiency and diet on adaptive variations in the bacterial community in the rumen fluid of cattle. Appl. Environ. Microbiol. 78:1203-1214.

Kelly, A. K., M. McGee, D. H. Crews Jr., T. Sweeney, T. M. Boland, and D. A. Kenny. 2010. Repeatability of feed efficiency, carcass ultrasound, feeding behaviour, and blood metabolic variables in finishing heifers divergently selected for residual feed intake. J. Anim. Sci. 88:3214-3225.

Lawrence, P., D. A. Kenny, B. Earley, D. H. Crews Jr., and M. McGee. 2011. Grass silage intake, rumen and blood variables, ultrasonic and body measurements, feeding behavior, and activity in pregnant beef heifers differing in phenotypic residual feed intake. J. Anim. Sci. 89:3248-3261

Lin, Z., I. Macleod, and J. E. Pryce. 2013. Short communication: Estimation of genetic parameters for residual feed intake and feeding behavior traits in dairy heifers. J. Dairy Sci. 96:2654-2656.

Primary Industries Standing Committee. 2007. Nutrient Requirements of Domesticated Ruminants. CSIRO Publishing, Collingwood, Australia.

Pryce, J. E., J. Arias, P. J. Bowman, S. R. Davis, K. A. Macdonald, G. C. Waghorn, W. J. Wales, Y. J. Williams, R. J. Spelman, and B. J. Hayes. 2012. Accuracy of genomic predictions of residual feed intake and 250-day body weight in growing heifers using 625,000 single nucleotide polymorphism markers. J. Dairy Sci. 95:2108-2119.

Rius, A. G., S. Kittelmann, K. A. Macdonald, G. C. Waghorn, P. H. Janssen, and E. Sikkema. 2012. Nitrogen metabolism and rumen microbial enumeration in lactating cows with divergent residual feed intake fed high-digestibility pasture. J. Dairy Sci. 95:50245034

Roche, J. R., P. G. Dillon, C. R. Stockdale, L. H. Baumgard, and M. J. VanBaale. 2004. Relationships among international body condition scoring systems. J. Dairy Sci. 87:3076-3079.

Tyrrell, H. F., and P. W. Moe. 1975. Effect of intake on digestive efficiency. J. Dairy Sci. 58:1151-1163.

Waghorn, G. C., and R. J. Dewhurst. 2007. Feed efficiency in cattleThe contribution of rumen function. Pages 111-123 in Meeting the Challenges for Pasture-Based Dairying. Proc. Australas. Dairy Sci. Sym. Melbourne, Australia.

Waghorn, G. C., K. A. Macdonald, Y. Williams, S. R. Davis, and R. J. Spelman. 2012. Measuring residual feed intake in dairy heifers fed an alfalfa (Medicago sativa) cube diet. J. Dairy Sci. 95:1462-1471.

Williams, Y. J., J. E. Pryce, C. Grainger, W. J. Wales, N. Linden, M. Porker, and B. J. Hayes. 2011. Variation in residual feed intake in Holstein Friesian dairy heifers in Southern Australia. J. Dairy Sci. 94:4715-4725. 